\title{
PERBANDINGAN NILAI BIOLOGIS PAKAN \\ LOKAL DAN IMPOR PADA ANAK \\ KUDA PACU INDONESIA
}

\author{
Cicilia M Manarisip, Y.L.R. Tulung*, W.B. Kaunang, R.A.V. Tuturoong
}

Fakultas Peternakan Universitas Sam Ratulangi Manado, 9511

\begin{abstract}
ABSTRAK
Penelitian ini bertujuan Untuk mengetahui kemampuan anak ternak kuda pacu dalam mencerna pakan, baik pakan lokal dan pakan impor.Kecernaan zat-zat makanan merupakan faktor yang sangat menentukan kualitas bahan pakan atau ransum yang dikonsumsi ternak kuda.Penelitian ini menggunakan metode Statistik t-test.Teknik pengambilan data adalah wawancara dan pengamatan langsung pada lokasi-lokasi peternakan kuda pacu. Data yang dikumpulkan yakni jenis pakan lokal (jagung, dedak, tepung ikan, kedele, kacang hijau, bungkil kelapa) dan jenis pakan impor (sustaina). Jumlah pakan (hijauan dan konsentrat) yang diberikan pada anak ternak kuda pacu memperoleh jumlah feses (g/ekor/hari) kemudian diambil sebanyak 12 sampel masing-masing 8 ekor kuda pacu yang menggunakan pakan lokal dan 4 ekor kuda pacu yang menggunakan pakan impor.Variabel yang diukur kecernaan energi dan kecernaan protein. Hasil penelitian yaitu kecernaan energi (pakan lokal $\pm 85,92$ dan pakan impor $\pm 87,58$ ) dan kecernaan protein (pakan lokal \pm 75,86 dan pakan impor $\pm 86,89$ ). Hasil uji t, menunjukan bahwa kecernaan energi pakan impor memberikan pengaruh yang tidak berbeda nyata $(\mathrm{P}>0.05)$ dibandingkan pakan lokal sedangkan kecernaan protein pakan impor berbeda sangat nyata $(\mathrm{P}<0.01)$ dibandingkan dengan pakan lokal. Berdasarkan hasil penelitian ini dapat disimpulkan bahwa

*Korespondensi (corresponding Author) Email: tulungyohannis@gmail.com

kecernaan protein untuk pakan impor lebih baik dibandingkan dengan pakan lokal.

Kata kunci: Ternak Kuda, Pakan Lokal,Pakan Impor, Kecernaan

ABSTRACT

COMPARISON OF BIOLOGICAL VALUE OF LOCAL AND IMPORT FEED IN INDONESIAN CHILD RACE HORSEThis research aims to determine the livestock child race horse's ability to digest feed, both local and imported feed. Digestibility of nutrients is a factor that determines the quality of feed ingredients or feed consumed by the livestock horses. This research used Statistics t-test method.Techniques of data retrieval are interviews and direct observations at sites of breeding racehorses. Data collected ie the type of local feed (corn, rice bran, fish meal, soybean, mung beans, coconut cake) and the types of imported feed (sustaina). The amount of feed (forage and concentrates) were given to livestock of child racehorse obtain the amount of feces ( $\mathrm{g} /$ head / day) is then taken as many as 12 samples each of 8 racehorses using local feed and 4 racehorses use imported feed. The variables measured are digestibility of energy and protein digestibility. The results of the research are digestible energy (local feed \pm 85.92 and imported feed \pm 87.58$)$ and protein digestibility (local feed \pm 75.86 and imported feed $86.89 \pm$ ). T test, showed that the energy digestibility of feed imports give effect not significantly different $(\mathrm{P}>0.05)$ compared
\end{abstract}


to local feed while the digestibility of protein feed imports significantly different $(\mathrm{P}<0.01)$ in comparison with the local feed. Based on these results it can be concluded that the digestibility of protein for imported feed better than the local feed.

Keywords: livestock horses, local feed, imported feed, digestibility

\section{PENDAHULUAN}

Kuda pacu sebagai ternak untuk diperlombakan mempunyai keunikan dalam hal mengkonsumsi pakan, sebab tujuan pemberian pakan adalah untuk mencapai prestasi yang baik pada saat pacuan, oleh sebab itu perlu diperhatikan pakan maupun zat-zat makanan yang terkandung dalam pakan.

Manajemen pemeliharaan kuda pacu, termasuk manajmen pemberian pakan di Indonesia sebagian besar masih mengacu pada pemberian pakan yang dilakukan oleh negara-negara maju. Hal ini disebabkan karena kebiasaan secara turun temurun serta faktor gengsi para peternak kuda maka peternak kuda lebih mengandalkan bahan baku pakan impor. Indonesia merupakan negara agraris di mana bahan baku pakan lokal berupa bijibijian dan hijauan cukup tersedia sebagai sumber pakan kuda. Kecernaan zat-zat makanan merupakan faktor yang sangat menentukan kualitas bahan pakan atau ransum yang dikonsumsi ternak kuda.Kuda termasuk hewan herbivora
nonruminan.Dari aspek pencernaan makanan, kuda digolongkan sebagai hewan dengan alat pencernaan perut bagian belakang (hindgut fermentor).Sistem pencernaan ternak kuda berbeda dengan ternak lainnya.Oleh karena itu perlu dilakukan penelitian untuk menguji kecernaan pakan karenatinggi rendahnya kecernaan bahan pakan memberikan arti seberapa besar bahan pakan itu mengandung zat-zat makanan dalam bentuk yang dapat dicernakan ke dalam saluran pencernaan. Kuda mempunyai keunikan pada sistem pencernaannya sehingga ternak tersebut digolongkan pada ternak herbivora nonruminansia karena kuda tidak melakukan proses ruminasi (memamahbiak) dan secara fisiologis tidak dapat melakukan regurgitasi (pengunyahan kembali) seperti pada ternak ruminansia.

\section{MATERI DAN METODE PENELITIAN}

\section{Tempat dan Waktu Penelitian}

Penelitian ini telah dilaksanakan di Lokasi peternak kuda pacu Desa Pinabetengan dan Pinaesaan Kecamatan Tompaso dari bulan Februari sampai dengan bulan Maret 2016.

\section{Materi Penelitian}

a) Ternak Percobaan 
Ternak yang digunakan dalam penelitian ini adalah kuda umur 13 - 24 bulan. Ternak yang digunakan dalam penelitian ini berjumlah 12 ekor anak kuda pacu, 8 ekor ternak yang mengkonsumsi pakan lokal dan 4 ekor ternak yang mengkonsumsi pakan impor.

b) Kandang dan Perlengkapan

Kandang yang digunakan adalah kandang individual yang digunakan oleh peternak kuda pacu.Pakan yang digunakan dalam penelitian ini adalah beberapa jenis pakan lokal (jagung, dedak, tepung ikan, kedele, kacang hijau, bungkil kelapa) yang diramu dalam bentuk konsentrat dan hijauan (rumput lapang, tebon jagung), pakan impor (sustaina).

c) Alat dan Bahan

Alat-alat yang digunakan dalam penelitian yaitu timbangan, kantong plastik dan alat tulis menulis. Untuk bahan-bahan yang digunakan yaitu jenis-jenis bahan pakan hijauan dan konsentrat sesuai dengan yang diberikan oleh peternak kuda pacu. Pakan hijauan yang digunakan adalah rumput Paspalum sp , tebon jagung dan pakan konsentrat terdiri dari pakan lokal dan impor.

\section{Metode Penelitian}

Penelitian ini menggunakan
metode Statistik t-test (Steel dan
Torrie,1991) dimana perlakuannya dua
jenis pakan impor dan pakan lokal.

\section{Variabel yang diamati \\ - Kecernaan Energi \\ - Kecernaan Protein}

Kecernaan energi dan protein dihitung berdasarkan rumus (Banerjee, 1978):

1. $\mathrm{KCE}=$

(Kons Rx EB R) $-\left(\sum\right.$ fesx EB fes $)$ (Kons $R x E B R$ ) $x 100 \%$

$\mathrm{KCE}$ : Koefisien cerna semu energi ransum $(\%)$

Konsumsi R : Jumlah ransum yang dikonsumsi (g.ekor ${ }^{-1} \cdot$ hari $\left.^{-1}\right)$

EBR : Energi bruto ransum(kkal.ekor ${ }^{-1}$.hari $\left.{ }^{-1}\right)$

$\sum$ fes : Jumlah feses yang didefikasi (g.ekor ${ }^{-1} \cdot$ hari $\left.^{-1}\right)$

EB feses :Energi bruto feses $\left(\right.$ kkal.ekor $^{-1} \cdot$ hari $^{-1}$ )

2. $\mathrm{KCE}=$

$\frac{(\text { Kons.Rx \% prot } R)-\left(\sum \text { fes } x \text { prot fes }\right)}{(\text { Kons } R x \% \text { prot } R)} \times 100 \%$

$\mathrm{KCE}$ : Koefisien cerna semu energi ransum $(\%)$

Konsumsi R : Jumlah ransum yang dikonsumsi (g.ekor ${ }^{-1} \cdot$ hari $\left.^{-1}\right)$

EB $\mathrm{R}$ : Energi bruto ransum(kkal.ekor ${ }^{-1}$.hari $^{-1}$ )

Prot R : Protein kasar ransum (\%) $\sum$ fes : Jumlah feses yang didefikasi (g.ekor ${ }^{-1} \cdot$ hari $\left.^{-1}\right)$

Prot fes : Jumlah feses yang didefikasi (g.ekor ${ }^{-1} \cdot$ hari $\left.^{-1}\right)$ $\%$ Prot Fes : Protein feses (\%) 
Tabel 1. Komposisi Pakan Lokal dan Pakan Impor

\begin{tabular}{lccccccc}
\hline Jenis Pakan & $\begin{array}{c}\mathrm{BK}^{*} \\
(\%)\end{array}$ & $\begin{array}{c}\text { Energi }^{*} \\
\text { Mkal }\end{array}$ & $\begin{array}{c}\text { Protein }^{*} \\
(\%)\end{array}$ & $\begin{array}{c}\text { Lemak }^{* *} \\
\%\end{array}$ & $\begin{array}{c}\mathrm{SK}^{* *} \\
\%\end{array}$ & $\begin{array}{c}\mathrm{Ca}^{* *} \\
\%\end{array}$ & $\begin{array}{c}\mathrm{P}^{* *} \\
\%\end{array}$ \\
\hline Lokal & 87.47 & 3.66 & 9.63 & 4.37 & 3.07 & 1.15 & 0.60 \\
Impor & 91.24 & 3.91 & 11.37 & 8.00 & 10.00 & 0.70 & 0.40 \\
$\quad$ Hijauan & & & & & & & \\
$-\quad$ Tebon jagung & 92.43 & 3.76 & 6.37 & 1.3 & 36.15 & 0.46 & 0.3 \\
$-\quad$ Rumput lapang & 87.76 & 3.16 & 9.63 & 1.65 & 34.64 & 0.67 & 0.44 \\
\hline Sumber :*) Hasil Analisa Laboratorium Ilmu dan Teknologi Pakan Institut Pertanian Bogor \\
(2016) \\
**) Hasil Analisis Laboratorium Ilm dan Teknologi Pakan Institut Pertanian Bogor, \\
(Tulung, 2007).
\end{tabular}

\section{Hipotesis}

H0 : Pakan lokal dan impor memberikan pengaruh tidak berbeda nyata terhadap kecernaan energi dan protein

H1 : Pakan lokal dan impor memberikan pengaruh yang nyata terhadapkecernaan energi dan protein atau minimal 1 pakan yang berbeda

\section{Tatalaksana Penelitian}

1. Tahap pendahuluan

Servei dan pengamatan langsung dilakukan dilokasi peternakan kuda pacu.Dilakukan pengumpulan data atau informasi peternak kuda dengan melakukan wawancara di lokasi peternakan kuda pacu.

2. Tahap koleksi

Pengumpulan feses dilakukan mulai pukul 06.00 wita sampai dengan keesokan harinya pada jam yang sama. Pengambilan sampel feses dilakukan sebanyak 7 kali untuk ternak kuda yang mengkonsumsi pakan lokal dan 1 kali untuk ternak kuda yang mengkonsumsi pakan impor. Setiap hari feses ditimbang total feses untuk setiap ternak dan mengambil sampel untuk kbutuhan analisis. Demikian juga dengan sampel pakan.

3. Analisis Sampel

Sampel pakan dan sampel feses dibawa di Balai Penelitian Ternak Laboratotium Bogor untuk dianalisis kandungan energi dan protein

\section{HASIL DAN PEMBAHASAN}

Hasil penelitian tentang rataan jumlah konsumsi pakan lokal dan pakan impor ditampilkan pada Tabel 2. Pada Tabel 2, 
ternyata kuda yang diberi pakan impor (konsentrat), mengkonsumsi hijauan maupun konsentrat lebih tinggi di bandingkan yang diberi pakan lokal. Hasil analisis t-Test: Two-Sample Assuming Unequal Variances menunjukkan adanya perbedaan yang sangat nyata $(\mathrm{p}<0.01)$ antara konsumsi bahan kering pakan impor dibandingkan dengan pakan lokal. Hal ini kemungkinan disebabkan karena anak kuda sebagai materi penelitian adalah G4 (75\% thoroughbred), sehingga lebih tinggi darah thoroughbred-nya maka konsumsi pakan impor lebih tinggi, sebab kuda throughbred yang merupakan kuda impor yang didatangkan dari Australia mengkonsumsi pakan impor (konsentrat) sebagai pakan utama.Tulung (2012) mengemukakan bahwa nilai biologis pakan menentukan jumlah konsumsi.

\section{Kecernaan Energi}

Tabel 3 menunjukkan nilai rataan kecernaan energi untuk pakan lokal dan pakan impor yaitu 85.925 dan 87.585, kecernaan pakan lokal lebih tinggi dari kisaran yang dikemukakan oleh Mende (2015) yaitu 77.774 tetapi pakan impor lebih rendah yaitu 88.639.Dari hasil tersebut menunjukkan pemberian pakan lokal dan pakan impor pada anak kuda pacu menghasilkan energi yang hampir sama dengan kecernaan energi untuk pakanlokal dan pakan impor pada kuda pacu dewasa. Hal ini disebabkan karena energi tercerna (DE) anak kuda pacu yaitu 13,37 Mcal lebih tinggi dibandingkan dengan NRC (2007) yaitu 12,2 Mcal. Berdasarkan Hasil analisis t-Test: TwoSample Assuming Unequal Variances menunjukkan kecernaan energi pakan impor memberikan pengaruh yang tidak berbeda nyata $(\mathrm{P}>0.05)$. Walaupun nilai kecernaan energi pakan impor lebih tinggi dari pakanlokaltetepi belum menunjukkan perbedaan yang nyata.Hal ini sejalan dengan pendapat Tulung (2012) yang menyatakan bahwa kuda pacu yang mengkonsumsi pakan lokal dan pakan impor tidak berbeda. Lebih lanjut dikemukakan bahwa, kebutuhan energi pada ternak sangat dipengaruhi olehpertumbuhan, aktivitas, kondisi lingkungan dan massa tubuh ternak.Potter et al. (1990) mengatakan sambil melakukan latihan, kuda mampu mendapatkan cukup oksigen ke jaringan untuk membakar lemak sebagai sumber energi Meghan dan Waller (2008) mengemukakan bahwa dasar utama untuk memutuskan kebutuhan kuda adalah gizi sehingga ia membuat persyaratan dengan lima kategori dasar pemenuhan gizi kuda tersebut salah satunya yaitu energi. Oldham et al. (1990) berpendapat sangat penting untuk diperhatikan bahwa kuda pacu menerima 
Tabel 2. Nilai Rataan Jumlah Konsumsi Kuda Pacu Indonesia dalam Bahan Kering

\begin{tabular}{cccc}
\hline Uraian & Hijauan $(\mathbf{g})$ & Konsentrat $(\mathbf{g})$ & Total Konsumsi (g) \\
\hline Pakan Lokal & 1094 & 3328 & 4422 \\
Pakan Impor & 1465 & 4579 & 6044 \\
\hline
\end{tabular}

Tabel 3. Nilai Rataan Kecernaan Energi dan Protein dari Kuda Pacu Indonesia yang Mengkonsumsi Pakan Lokal dan Pakan Impor

\begin{tabular}{ccc}
\hline & Pakan Lokal (\%) & Pakan Impor (\%) \\
\hline Kecernaan Energi & \pm 85.925 & \pm 87.585 \\
Kecernaan Protein & \pm 75.867 & \pm 86.893 \\
\hline
\end{tabular}

energi yang cukup tersedia dari karbohidrat dalam bahan pakan guna untuk menjaga kadar gula darah dan menyimpan energi dalam bentuk glycogen otot karena ini adalah sumber energi (bahan bakar) utama untuk kuda. Ternak kuda yang sedang menyusui sampai umur satu tahun membutuhkan energi yang tinggi. Beberapa hasil penelitian juga menunjukkan bahwa kebutuhan energi yang digunakan dipengaruhi oleh usia ternak, hal ini sejalan dengan pendapat Johnson (2009) yaitu kebutuhan energi dan nutrien kuda berbeda dari individu ke individu dan di pengaruhi oleh massa tubuh kuda, usia dan efisiensi metabolisme.

\section{Kecernaan Protein}

Nilai rataan kecernaan protein untuk pakan lokal dan pakan impor pada Tabel 3 yaitu 75.867 dan 86.893. Hasil analisis t-Test: Two-Sample Assuming Unequal Variances menunjukkan bahwa kecernaan protein pakan impor dan pakan lokal berbeda sangat nyata $(\mathrm{P}<0.01)$. Berdasarkan hasil analisis t-Test: TwoSample Assuming Unequal Variances penggunaan pakan impor yang dikonsumsi anak kuda pacu Indonesia mengandung nilai kecernaan protein yang lebih tinggi dibandingkan dengan pakal lokal. Hal ini disebabkan karena kandungan nutrisi pakan impor lebih baik dari pada pakan lokal, sehingga menghasilkan kecernaan protein lebih tinggi pada pakan impor.Tulung (2012) mengatakan bahwa nilai biologis pakan lokal lebih rendah dibandingkan pakan impor sehingga walaupun tinggi jumlah konsumsi protein, tetapi sedikit yang siap digunakan karena nilai biologisnya rendah.Secara umum kuda pada fase pertumbuhan perlu persentase protein yang lebih tinggi dari kuda dewasa.Hal ini sejalan dengan pendapat Johnson at al. (2009) yang menyatakan bahwa kuda membutuhkan 
lebih banyak protein ketika jaringan sedang diatur untuk pertumbuhan (anak kuda), yaitu dalam fase pertumbuhan yang cepat. Hal ini sejalan dengan pendapat Freeman at al. (1988) bahwa untuk pemberian pakan yang tinggi kandungan protein untuk kuda dewasa tidak menguntungkan karena akan mengakibatkan pada peningkatan bobot badan yang berdampak pada penurunan prestasi saat dipacu, begitupun sebaliknya.

\section{KESIMPULAN}

Berdasarkan hasil penelitian ini dapat disimpulkan bahwa kecernaan protein untuk pakan impor lebih baik dibandingkan dengan pakan lokal.

\section{DAFTAR PUSTAKA}

Banerjee, 1978.Animal Nutrition.Oxford LBH Publ. Co. Calcutta. Bombay. New Delhi.

Freeman DW, Potter GD, Scheling GT, Kreider JL. 1988. Nitrogen metabolis in mature horses at varying of work. J. Anim. Sci. 66 : 407.

Johnson Pj, Charles W, Nat TG Venkataseshu EM. 2009. Medical implications of obesity in horseslessons for human obesity. Jurnal of diabetes science and technology 2009;3(1);163-74.

Meghan W, Waller A. 2008. All tied up: metabolic factors and nutritional management of aquine exertional rhabdomyolysis. J. Eq. Vet. Vol. 19, Issue 5, pages 392-397

Mende, I. S. 2015. Kecernaan Energi, Protein dan Mineral Kalsium dan Fosfor Kuda Pacu Minahasa yang Diberikan Pakan Lokal dan Impor. Jurnal Zootek ("Zootek" Journal ) Vol. 35 No. $1: 30-38$

National Rearce Council, 2007. NutrientRequirements of Horses. $5^{\text {th }}$ Revised ed. National Academy Press. Washington DC.

Oldham, S. L., G. D. Potter, J. W. Evans, S. B. Smith, T. S. Taylor dan W. S. Barnes. 1990. Storage and mobilization of muscle glycogen in exercising horses fed a fatsupplemented diet. Journal of Equine Veterinary Science. $10(5): 1-5$.

Potter, G. D., S. P. Webb, J. W. Evans dan G. W. Webb. 1990. Digestible energy requirements for work and maintenance of horses fed conventional and fat supplemented diets. Journal of Equine Veterinary Science. 10(3):214-218.

Steel, R.G.D. dan J.H. Torrie. 1991. Prinsip dan Prosedur Statistika: Suatu Pendekatan Biometrik, Edidi Kedua,P.T Gramedia Utama.Jakarta.

Tulung, Y.L.R. 1998. Pendugaan Kebutuhan Energi Tercerna dan Protein Kasar Kuda Pacu Minahasa.Tesis.Program

Pascasarjana Institut Pertanian Bogor. Bogor.

. 2012. Kebutuhan Energi dan Protein Kuda Pacu Indonesia dan Aplikasi Pada Formulasi Ransum Berbasis Bahan Pakan 
Lokal.Disertasi.Program

Pascasarjana, IPB. Bogor. 
